\title{
Labor market insecurity among the middle class: a cross-pressured group
}

\author{
Hanna Schwander* \\ Hertie School of Governance, Berlin, Germany \\ *Corresponding author. Email: schwander@hertie-school.org
}

(Received 16 May 2018; accepted 12 July 2018; first published online 12 April 2019)

\begin{abstract}
The political relevance of labor market insecurity has been questioned because (a) insider-outsider divides were considered to be a divide within the low-skilled and politically less active working class and (b) labor market insecurity runs through the middle of the household. Outsiders might therefore align their preferences with those of insiders. This contribution provides, first, evidence that labor market insecurity extends well into the higher-skilled middle class, in particular to high-skilled young adults and high-skilled women. Second, the contribution sheds light on the "household question", that is the question whether mixed households dampen the political relevance of labor market insecurity. If labor market insecurity is concentrated in specific social groups (young adults, women) that tend to cohabit with secure insiders, the political relevance of labor market insecurity might depend on whether or not outsiders align their preferences with those of the household. In this contribution, I discuss recent work on the relevance of the household in translating labor market divides into preferences divides presenting recent work that shows that the household does not render insider-outsider divides politically irrelevant. In sum, insider-outsider divides have all the potential to become politically relevant.
\end{abstract}

Keywords: Comparative politics; industrialized countries; political economy; political participation and turnout; voting behavior

\section{Introduction}

The political relevance of labor market insecurity has been questioned because (a) insideroutsider divides were considered to be a divide within the low-skilled and politically less active working class (Berger and Piore 1980; Rueda and King 2008) and (b) labor market insecurity runs through the middle of the household (Pierson 2001; Emmenegger 2010). Outsiders might therefore align their preferences with those of insiders. Building on previous research (Schwander and Häusermann 2013; Häusermann et al. 2015; Schwander 2017, 2018), this contribution shows that these claims do not hold true. I provide evidence that labor market insecurity extends well into the higher-skilled middle class, in particular to high-skilled young adults and high-skilled women. Responsible for this spread of labor market insecurity is a dual transformation of post-industrial labor markets. First, labor markets have become less stable and dualized. Second, the growth of the middle class resulted in more heterogeneous work conditions within the middle class. The spread of labor market insecurity into the middle class and in particular its gendered nature bear relevance for the "household question", that is the question whether mixed households dampen the political relevance of labor market insecurity. If labor market insecurity is concentrated in specific social groups (young adults, women) that tend to cohabit with secure insiders, the political relevance of labor market insecurity might depend on whether or not

(C) The European Political Science Association 2019. This is an Open Access article, distributed under the terms of the Creative Commons Attribution licence (http://creativecommons.org/licenses/by/4.0/), which permits unrestricted re-use, distribution, and reproduction in any medium, provided the original work is properly cited. 
outsiders align their preferences with those of the household. In this contribution, I will discuss recent work on the relevance of the household in translating labor market divides into preferences divides.

\section{The dual transformation of post-industrial labor markets}

The first transformation of post-industrial labor market, the increase in labor market insecurity and its unequal distribution represents the motivation of this symposium. Besides the reemergence of unemployment in labor market statistics again, we also witness the emergence of "new" labor market risks such as temporary or part-time employment, agency work or pseudo self-employment (Palier and Thelen 2010; Emmenegger et al. 2012). Some scholars even speak of a "new social divide not based on earning differentials, but based on access to good jobs" (Oesch 2015).

The insider-outsider literature has developed different conceptualizations of insiders and outsiders to get at this new divide (see the contribution by Georg Picot and Paul Marx to this symposium, as well as Schwander and Häusermann 2013). Here, I rely on the concept of labor market vulnerability that identifies a situation where an individual is permanently exposed to high labor market risks (see Schwander and Häusermann 2013). Such a continuous and risk-based understanding of insiders and outsiders is best suited to capture the implications of labor market insecurity for politics (see the contribution by Tim Vlandas).

An equally important change in post-industrial labor markets is the growth of the middle class, which is the result of three structural and interlinked trends: the tertiarization, feminization and educational up-grading of the employment structure (Oesch 2015). It is well known that the employment structure has become more service oriented over the last decades. Most important for this contribution's question, these service jobs are characterized by a greater heterogeneity of work conditions. The second trend, the educational revolution, was both a driver and consequence of the tertiarization of the employment structure. When the educational attainment of younger cohorts increased, firms adapted their production strategies to the abundant supply of highly skilled professionals and semi-professionals and offered jobs in the expanding sectors of health, education and social services but also in business and financial services (Wren et al. 2013; Ansell and Gingrich 2018). Many of these new jobs were taken by women, although with considerable variation with regard to timing and extent (Estévez-Abe 2006; EspingAndersen 2009). This third trend, the feminization of the workforce, has accelerated since the 1990s and contributed substantially to the occupational upgrading when women's educational catch-up translated in higher occupational attainment and their share in high-paid and high skilled jobs expanded (Oesch 2015).

Taken together, the structural transformations resulted in increasingly heterogeneous work conditions of a growing middle class giving way to new divides within the middle class.

\section{Why parts of the middle class have become more vulnerable}

I want to emphasize that this is not to argue that skills or educational attainment are irrelevant for success in the labor market. Quite in contrast, higher education pays a higher wage premium than ever in the post-war period and is essential for a stable career. Yet, not all high-skilled groups do equally well in post-industrial labor markets. Women and young adults face different labor market prospects than men and elderly labor market participants and constitute highly skilled but vulnerable groups (see Schwander and Häusermann 2013, Häusermann et al. 2015, Schwander 2017).

Young adults encounter a variety of risks when entering the labor market and require time to acquire a stable position in the labor market. Some of this insecurity represents the normal transition from education to work, however, the transition period has become prolonged in post- 
industrial labor markets and many young adults move from one temporary job to another. Rigid employment protection or the importance of internal labor markets hamper the integration of young adults, keeping them in temporary jobs or unemployment and exacerbating their labor market vulnerability (Müller and Gangl 2003, Ansell and Gingrich 2018). The "selective" flexibilization at the margins of labor markets (Toharia and Malo 2000) which left the privileges of the core workers untouched but introduced flexible forms of employment for those at the margins is another reason for the difficulties of young adults (Polavieja 2005). In this context, the deregulation of labor markets engenders a dualization of labor market chances even among the high-skilled.

Similarly, female employment rates are still lower and unemployment rates are higher than men's. This is often related to their still lower educational attainment or the function of female employees as "employment buffer'. In addition to these risks, women face additional employment risks due to their biological role as birth-giver and social role as care-giver (Estévez-Abe 2006). Consequently, atypical employment is the employment reality of many women regardless of their skill level, in particular if national labor market, welfare state and tax institutions acerbate difficulties to combine family and employment demands as in continental and southern Europe (Esping-Andersen 2009; Hook 2015).

\section{Atypical employment as employment reality for high-skilled women or young adults}

The following section provides evidence for the arguments put forward. Based on pooled data from the European Labor Force Survey, Figure 1 presents rates of temporary and part-time employment for the workforce and for the two high-skilled segments that are particularly likely to be affected by labor market risks. The corresponding figures for unemployment as well as the individual country patterns can be found in the Supplementary Material (Figures A.1-A.4).

Figure 1 confirms that high-skilled women and younger workers are not spared from atypical employment. The left-hand side of Figure 1 shows the steady rise of part-time employment in Western Europe (solid line). This trend does not stop short before the group of high-skilled women as the parallel movement of the dotted line shows. High-skilled women are even more likely to work part-time than the average member of the workforce, a pattern valid in all countries. While high-skilled young adults are less likely to work in part-time employment than the average worker, their rate of part-time employment raises in parallel with the general trend, indicating that part-time employment spreads to the segment of high-skilled young adults as well.

Just as part-time employment is a highly gender-biased labor market risk, temporary employment is strongly age-biased and employment reality increasingly also for high-skilled young adults the right-hand side of Figure 1 shows. The rate of temporary employment of young adults exceeds the average rate of temporary employment in all countries but temporary employment is also biased against higher skilled women in approximately half the countries. During the Great Recession (2008-2012) temporary employment in general and among high skilled young adults came to a halt and was even receding among high-skilled women. Considering that temporary employed are among the first to lose their job during economic downturns, this does not come as a surprise but emphasizes the precarity of these jobs also for high-skilled. To conclude, substantial segments of the high-skilled population were exposed to labor market risks. Middle class vulnerability is mainly a result of new labor market risks for atypical work rather than unemployment risk, although the Great Recession increased unemployment risks for high-skilled young adults too (see Figure A.1).

The feminization of the workforce and the gendered nature of labor market insecurity lead to "mixed households", when female outsiders live with male insiders. This raises questions about the role of the household in translating labor market divides into political divides. For those outsiders, the household represents a "safety net" (Pierson 2001; Emmenegger 2010). The argument goes that outsiders will base their political behavior of the situation of the household, rather than 

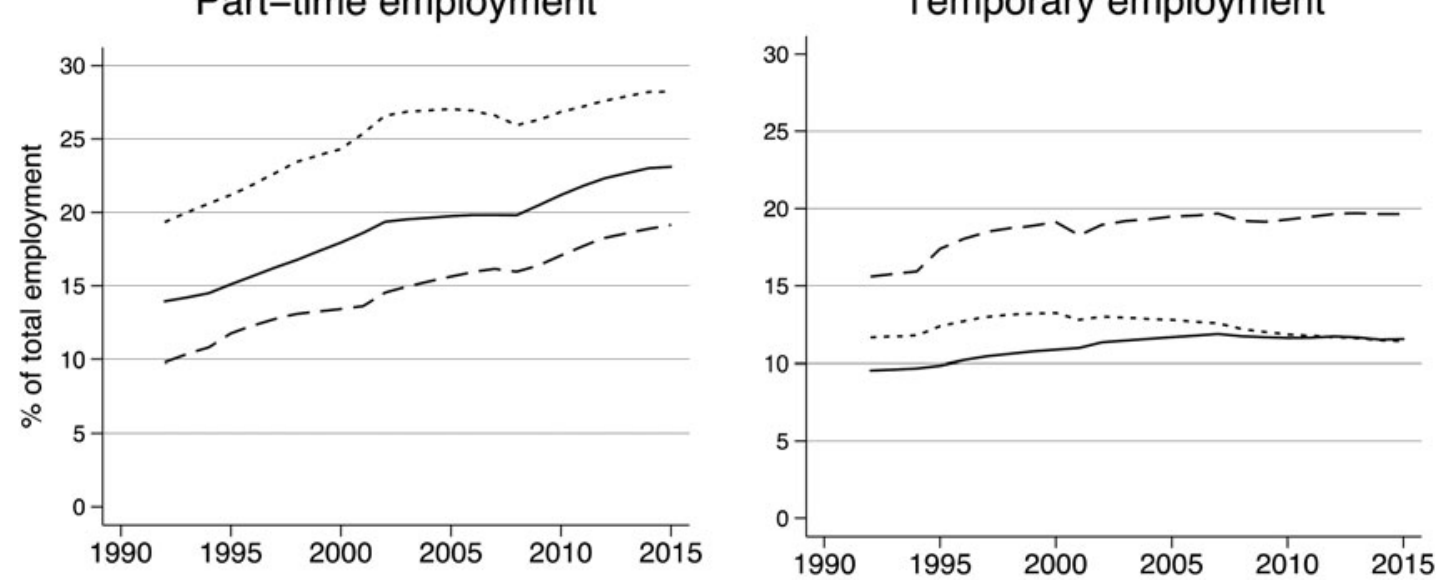

Workforce

\section{- - - High-skilled young adults}

High-skilled women

Figure 1. The spread of atypical employment to the middle class in Western Europe.

Note: Higher education denotes post-secondary or tertiary education and young adults are aged between 18 and 36 years. Data includes Belgium, Germany, Denmark, Finland, France, Greece, Ireland, Italy, Luxembourg, the Netherlands, Norway, Portugal, Spain, Sweden and the UK. 
on their personal situation. The household issue touches the old question whether the individual or the household represents the adequate unit of analysis, a question also vivid in the voting literature (Strøm 2014), in political economy (Iversen and Rosenbluth 2006) and sociology (Graaf and Heath 1992). A recent study tackled this question explicitly and tested the relevance of the household in the translation of labor market divides into preference-divides (Häusermann et al. 2016). Based on cross-section data from 13 European countries, the study found that the household does indeed represent a safety net for outsiders, but only for a minority (between 2 and 13 percent of the working population). For most individuals (men, secure women, insecure women living with a reasonably stable or instable partner, those without household), however, their personal situation remains crucial for their political preferences. Hence, the household does not constitute an obstacle for a politicization of the labor market insecurity. Further research is needed to investigate the relevance of the parental household for the political behavior of young outsiders.

\section{Conclusion}

The main argument put forward in this contribution is that education and labor market insecurity are not collinear phenomena. The reason for this lies in the dual transformation of postindustrial labor markets: not only have labor markets become more unstable and atypical work more prevalent but a growing middle class has become more heterogeneous in terms of working conditions and job prospects. Hence, the contribution points to the importance of treating labor market insecurity and education as two distinct dimensions in the discussion of labor market inequality, stratification and dualization (see Philip Rehm's contribution for a similar argument regarding income inequality).

So far, the main political implication of labor market divides lies in their political alienation expressed by non-voting or casting a protest-vote (Häusermann and Schwander 2012; Emmenegger et al. 2015; Rovny and Rovny 2017; Schwander 2018) but as labor market insecurity affects increasingly the politically active middle class, so might the political consequences (see Bürgisser and Kurer 2016). Relevant for a politicization is also the question of "mixed households", when insecure female outsiders live with stable male insider. Based on recent evidence, the contribution concludes that the household is not an obstacle to a politicization of labor market inequality. Indeed, the recent erosion of men's secure labor market position in the wake of the Great Recession might lead to an intensified politicization of labor market insecurity as men base their political preferences on their personal situation and might act as a multiplicator if their dependent family members vote on the household situation (Häusermann et al. 2016). The sweeping success of populist parties across Europe might be a sign of this (see Manow and Schwander 2019 and Silja Häusermann's contribution).

Supplementary Material. The supplementary material for this article can be found at https://doi.org/10.1017/psrm.2019.11

\section{References}

Ansell B and Gingrich J (2018) Skills in demand? Higher education and social investment in Europe. In Manow P, Palier B and Schwander H (eds), Welfare Democracies and Party Politics. Explaining Electoral Dynamics in Times of Changing Welfare Capitalism. Oxford: Oxford University Press, pp. 225-255.

Berger S and Piore MJ (1980) Dualism and Discontinuity in Industrial Societies. Cambridge: Cambridge University Press. Bürgisser R and Kurer T (2016) Inert and Insignificant? On the Electoral Relevance of Labor Market Outsiders. paper presented at the Annual Meeting of the Swiss Political Science Association in Basel, Switzerland, January 21-22, 2016.

Emmenegger P (2010) Gendering insiders and outsiders: labour market Status and preferences for Job security. RECWOWE working paper series 2010 (2).

Emmenegger P, Häusermann S, Palier B and Seeleib-Kaiser M (2012) The Age of Dualization. The Changing Face of Inequality in Deindustrializing Societies. New York and Oxford: Oxford University Press.

Emmenegger P, Marx P and Schraff D (2015) Labour market disadvantage, political orientations and voting: how adverse labour market experiences translate into electoral behaviour. Socio-Economic Review 13, 189-213. 
Esping-Andersen G (2009) The Incomplete Revolution. Adapting Welfare States to Women's New Roles. Cambridge: Polity Press.

Estévez-Abe M (2006) Gendering the varieties of capitalism. A study of occupational segregation by sex in advanced industrial societies. World Politics 59, 142-175.

Graaf NDD and Heath A (1992) Husbands' and wives' voting behaviour in britain: class-dependent mutual influence of spouses. Acta Sociologica 35, 311-322.

Häusermann S and Schwander H (2012) Varieties of dualization? Labor market segmentation and insider-outsider divides across regimes. In Emmenegger P, Häusermann SPalier B and Seeleib-Kaiser M (eds), The Age of Dualization. The Changing Face of Inequality in Deindustrializing Societies. Oxford and New York: Oxford University Press, pp. 27-51.

Häusermann S, Kurer T and Schwander H (2015) High-skilled outsiders? Labor market vulnerability, education and welfare state preferences. Socio-Economic Review 13, 235-258.

Häusermann S, Kurer T and Schwander H (2016) Sharing the risk? Households, labor market vulnerability and social policy preferences in Western Europe. Journal of Politics 78, 1045-1060.

Hook JL (2015) Incorporating 'class' into work-family arrangements: insights from and for three worlds. Journal of European Social Policy 25, 14-31.

Iversen T and Rosenbluth F (2006) The political economy of gender: explaining cross-national variation in the gender dividion of labor and the gender voting Gap. American Journal of Political Science 50, 1-19.

Manow P and Schwander H (2019) A Labor market explanation for right-wing populism. Explaining the electoral success of the AFD in Germany. Unpublished manuscript.

Müller W and Gangl M (2003) Transformations from Education to Work in Europe: The Integration of Youth Into EU Labour Markets. Oxford: Oxford University Press.

Oesch D (2015) Occupational structure and labour market change in Western Europe since 1990. In Beramendi P, Häusermann S, Kitschelt H and Kriesi H (eds), The Politics of Advanced Capitalism. Cambridge: Cambridge University Press, pp. 112-132.

Palier B and Thelen KA (2010) Institutionalizing dualism: complementaries and change in France and Germany. Politics \& Societies 38, 119-148.

Pierson P (2001) Coping with permanent austerity: welfare state restructuring in affluent democracies. In Pierson P (ed.), The New Politics of the Welfare State. Oxford: Oxford University Press, pp. 410-456.

Polavieja JG (2005) Flexibility or polarization? Temporary employment and Job tasks in Spain. Socio-economic Review 3 , 233-258.

Rovny J and Rovny AE (2017) Outsiders at the ballot box: operationalizations and political consequences of the insideroutsider dualism. Socio-Economic Review Advance Access published January 10, 2017.

Rueda D and King D (2008) Cheap labor: the New politics of 'bread and roses' in industrial democracies. Perspectives on Politics 6, 279-297.

Schwander H (2017) Dualization of the welfare state and its impact on inequality in labor market risk. In Wulfgramm M, Bieber T and Leibfried S (eds), Welfare State Transformations in the 21st Century: Effects on Social, Economic and Political Inequality in OECD Countries. Basingstoke: Palgrave MacMillan, pp. 185-218.

Schwander H (2018) Labor market dualization and insider-outsider divides: why this New conflict matters. Political Studies Review Online First August 2018. doi: 10.1177/1478929918790872.

Schwander H and Häusermann S (2013) Who's in and who's out? A risk-based conceptualisation of insiders and outsiders. Journal of European Social Policy 23, 248-269.

Strøm M (2014) How husbands and wives vote. Electoral Studies 35(Suppl. C), 215-229. https://doi.org/10.1016/j.electstud. 2014.01.006.

Toharia L and Malo MA (2000) The spanish experiment: Pros and cons of flexibility at the margin. In Esping-Andersen G and Regini M (eds), Why Deregulate Labour Markets? Oxford and New York: Oxford University Press, pp. 307-335.

Wren A, Fodor M and Theodoropoulou S (2013) The trilemma revisited: Institutions, inequality, and employment creation in an Era of ICT-intensive service expansion. In Wren A (ed.), The Political Economy of the Service Transition. Oxford: Oxford University Press, pp. 108-146.

Cite this article: Schwander H (2020). Labor market insecurity among the middle class: a cross-pressured group. Political Science Research and Methods 8, 369-374. https://doi.org/10.1017/psrm.2019.11 